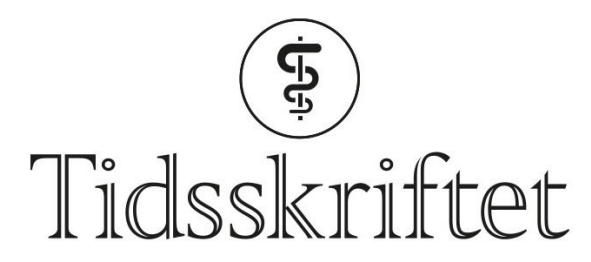

DEN NORSKE LEGEFORENING

\title{
Brystkreftrisiko hos transpersoner
}

FRA ANDRE TIDSSKRIFTER

KETIL SLAGSTAD

Institutt for helse og samfunn

Universitetet i Oslo

Kjønnsbekreftende eller kroppsjusterende hormonbehandling medfører noe økt brystkreftrisiko. Screeningprogrammene må tilpasses slik at transpersoner ikke går glipp av viktig helsehjelp.

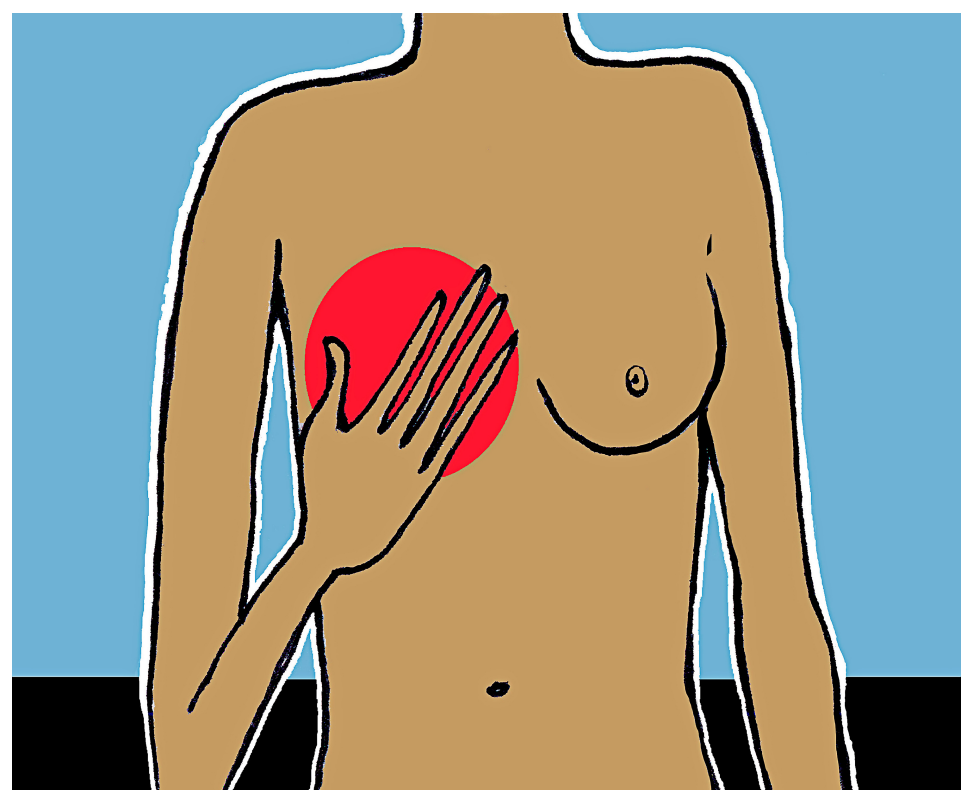

Illustrasjon: Science photo library / NTB Scanpix

Hos transpersoner er det manglende samsvar mellom kjønn tildelt ved fødsel og kjønnsidentitet eller kjønnsuttrykk. Mange ønsker hormonell og/eller kirurgisk kjønnsbekreftende eller kroppsjusterende behandling. Hos transkvinner, dvs. en kvinne som ble tildelt mannlig kjønn ved fødsel, kan dette omfatte antiandrogener og østrogener. Hos transmenn, dvs. en mann som ble tildelt kvinnelig kjønn ved fødsel, er behandlingen som regel testosteron. Slike hormonbehandlinger kan påvirke risikoen for brystkreft.

En retrospektiv kohortstudie som nylig er publisert i tidsskriftet BMJ, omfattet over 2200 transkvinner og 1200 transmenn i perioden 1972-2016 (1). Medianalder for oppstart av hormonbehandling var hhv. 31 og 23 år. Totalt 15 tilfeller av invasiv brystkreft ble oppdaget hos transkvinnene, der medianalder ved diagnosetidspunkt var 50 år etter median 18 års behandling. De fleste svulstene var østrogen- og progesteronreseptorpositive (hhv. 83\% og $67 \%$ ), mens langt færre var HER-2-reseptorpostive (8\%). Fire transmenn fikk diagnostisert 
invasiv brystkreft ved median alder 47 år og etter median 15 års behandling. Transkvinner som fikk hormonbehandling, hadde betydelig $ø$ kt relativ risiko for brystkreft sammenliknet med cismenn, dvs. menn tildelt mannlig kjønn ved fødsel, men risikoen for kreft var lavere for både transkvinner og transmenn som fikk hormonbehandling, enn hos ciskvinner, dvs. kvinner tildelt kvinnelig kjønn ved fødsel. Den absolutte risikoen for brystkreft hos transpersoner var likevel lav. Forfatterne anbefaler at transkvinner som bruker hormoner, og transmenn som ikke har utført mastektomi, bør følge det vanlige screeningprogrammet for brystkreft.

Leger må kjenne til hvordan kroppene til pasientene er satt sammen uavhengig av identitet, personnummer og tildelt kjønn. Selv om det er rapportert om få tilfeller av prostatakreft hos transkvinner, bør pasientene følges med familieanamnese og prostataundersøkelse på lik linje med cismenn (2). I Norge er tilgang til screeningprogrammene knyttet til kjønnet i personnummeret. Kreftregisteret gjør ikke unntak for enkeltpersoner: En person med mannlig personnummer kan ikke bli del av mammografiprogrammet, selv om han far hormonbehandling og har bryster, og en transmann med mannlig personnummer som ikke har fjernet livmor og livmorhals, får ikke innkalling til livmorhalsscreening.

Vi trenger mer fleksible ordninger som er tilpasset de kroppene folk faktisk har. Fastleger må kunne melde inn unntak til screeningprogrammene. Rigide systemer må ikke stå i veien for at folk får tilgang til viktig helsehjelp.

\section{LITTERATUR:}

1. de Blok CJM, Wiepjes CM, Nota NM et al. Breast cancer risk in transgender people receiving hormone treatment: nationwide cohort study in the Netherlands. BMJ 2019;365: 11652. [PubMed][CrossRef]

2. Deebel NA, Morin JP, Autorino R et al. Prostate cancer in transgender women: incidence, etiopathogenesis, and management challenges. Urology 2017; 110: 166-71. [PubMed][CrossRef]

Publisert: 12. august 2019. Tidsskr Nor Legeforen. DOI: 10.4045/tidsskr.19.0367

(C) Tidsskrift for Den norske legeforening 2020. Lastet ned fra tidsskriftet.no 